\section{Overseeding Bentgrass Species into Existing Stands of Annual Bluegrass}

\author{
Gerald M. Henry, Stephen E. Hart, ${ }^{1}$ and James A. Murphy \\ Dept. of Plant Biology and Pathology, Rutgers, The State University of New \\ Jersey, New Brunswick, NJ 08901
}

Additional index words. Agrostis canina, Agrostis stolonifera, Poa annua spp. reptans

\begin{abstract}
Field trials were conducted in 2000 and 2001 to determine the potential of converting pure stands of annual bluegrass [Poa annua L. spp. reptans (Hauskins) Timm.], maintained at a 3.2-mm height, to bentgrass (Agrostis spp.). Parameters evaluated included three overseeding dates and four cultivars from two bentgrass species. Overseeding dates were 1 July, 18 Aug., and 18 Sept. 2000 and 27 June, 17 Aug., and 17 Sept. 2001. Three creeping bentgrass ( $A$. stolonifera $\mathbf{L}$.) cultivars ('Penncross', 'L-93', and 'Penn A-4') and one velvet bentgrass ( $A$. canina $\mathrm{L}$.) cultivar ('SR7200') were evaluated. Initial bentgrass establishment was evident across all seeding dates and cultivars in October of the year of overseeding. However, the 1 July 2000 and 27 June 2001 overseeding dates had the highest levels of bentgrass coverage 12 months after overseeding across all cultivars except 'Penncross'. Coverage of 'Penn A-4' and 'L-93' increased to 72\% in the 1 July 2000 overseeding date, 24 months after the initial overseeding. When overseeded in early summer, velvet bentgrass 'SR7200' showed the greatest potential for establishment with annual bluegrass. 'SR7200' and creeping bentgrass cultivars 'Penn A-4' and 'L-93' exhibited the greatest potential for long-term competitiveness with annual bluegrass, while 'Penncross' exhibited the lowest potential.
\end{abstract}

Traditional renovation practices usually involve the desiccation of existing turf through the application of a nonselective herbicide followed by seedbed preparation(Turgeon, 1996). An alternative method involves the gradual conversion of annual bluegrass (AB) stands to a predominantly bentgrass turf through overseeding. Success of conversion has been modest in the few studies performed to evaluate gradual conversion through overseeding. Gaussoin and Branham (1989) obtained no more than $8 \%$ bentgrass conversion of a mixed $\mathrm{AB}$-creeping bentgrass stand after three years of overseeding with 'Penncross' creeping bentgrass. Reicher and Hardebeck (2002) observed no more than 3\% bentgrass conversion of a primarily $\mathrm{AB}$ fairway after 3 years of overseeding 'Penneagle' creeping bentgrass.

AB can exist as an annual (Poa annua spp. annua L. Timm.) or perennial biotype [Poa annua spp. reptans L. (Hauskins) Timm.] in turf sustained at low mowing heights and is one of the most problematic weeds in golf course fairways, tees and greens (Lush, 1989; Sweeney and Danneburger, 1997). Infestation is primarily due to cultural mismanagement of the turf environment and/or noncompetitiveness of bentgrass cultivars (Beard, 1970). Cultural practices such as irrigation, fertilization, mowing, and aeration intended to increase the use and attractiveness of desired turfgrass species can also act to promote $\mathrm{AB}$ infestation (Sprague

Received for publication 10 June 2004. Accepted for publication 3 Sept. 2004. The authors gratefully acknowledge the financial support provided by the New Jersey Turfgrass Association and the Center for Turfgrass Science, Rutgers University. The authors would like to acknowledge Darren Lycan and T.J. Lawson for their technical assistance.

${ }^{1}$ To whom reprint requests should be addressed; e-mail Hart@Aesop.Rutgers.Edu. and Burton, 1937). Dense populations of AB in a mixed $A B$-bentgrass stand can crowd out creeping bentgrass by out-competing it for light, water, and nutrients (Sprague and Burton, 1937), particularly during the cooler months of late fall through early spring.

$\mathrm{AB}$ produces an abundance of seedheads, even at low mowing heights, causing the turf to appear gray and tattered (Beard et al., 1978; Sprague and Burton, 1937) and reducing the playability of golf course fairways and putting green surfaces. $\mathrm{AB}$ exhibits poor heat (Wehner and Watschke, 1981) and drought tolerance (Carroll, 1943) and may thin and die when subjected to heavy persistent traffic. To sustain the health of $A B$, it is necessary for turfgrass professionals to apply relatively high levels of nitrogen, irrigation, and fungicides during the summer months (Turgeon, 1996).

Improved bentgrass cultivars have increased disease resistance and enhanced tolerance to close mowing, traffic, and temperature extremes (Bonos et al., 2001). Higher shoot densities of the newer creeping bentgrass cultivars can compete better with $\mathrm{AB}$ (Croce et al., 1998; Beard et al., 2001). Beard et al. (2001) concluded that creeping bentgrass cultivars able to maintain shoot densities $>2000$ shoots $/ \mathrm{dm}^{2}$ exhibited the most competitiveness in suppressing AB encroachment. Velvet bentgrasses are prostrate, stoloniferous grasses with fine leaf texture and high shoot density that produce a lush, velvet-like stand(DeFrance et al., 1952; Sprague and Evaul, 1930). Velvet bentgrasses have been used in place of creeping bentgrasses in cool, moist, oceanic climates found predominantly in New England and the Pacific Northwest (Christians, 1998). There has been increased interest in using velvet bentgrass outside of these geographic regions due to its excellent heat, drought, and low temperature tolerance (Beard, 1973).
The objectives of this study were to determine the effects of overseeding date and cultivar on the establishment of bentgrass into an existing, relatively pure stand of $\mathrm{AB}$. The competitiveness of 'L-93', 'Penn A-4', and 'Penncross' creeping bentgrass and 'SR7200' velvet bentgrass with $\mathrm{AB}$ was also evaluated over 2 years.

\section{Materials and Methods}

Overseeding experiments were conducted in 2000 and 2001 in North Brunswick, New Jersey on a Nixon sandy loam (fine-loamy, mixed, semiactive mesic typic Hapludults) with a $\mathrm{pH}$ of 6.3 and organic matter content of $30 \mathrm{~g} \cdot \mathrm{kg}^{-1}$. The AB turfs used in the 2000 and 2001 overseeding studies were established in September 1999 and 2000, respectively, at a seeding rate of $73 \mathrm{~kg} \cdot \mathrm{ha}^{-1}$ with petersons creeping bluegrass [Poa annua L. spp. reptans (Hauskins) Timm.] (Green Seed Co., Springfield, Mo.) and mowed five times per week to a height of $3.2 \mathrm{~mm}$. Irrigation was applied as needed to optimize $\mathrm{AB}$ growth and fertilizer $(16 \mathrm{~N}-1.7 \mathrm{P}-6.6 \mathrm{~K})$ was applied at a rate of $\mathrm{N}$ at 24 to $37 \mathrm{~kg} \cdot \mathrm{ha}^{-1} \cdot \mathrm{mo}^{-1}$ from March to November.

A $3 \times 5$ factorial arranged in a split plot design with three replications was used to evaluate overseeding date (main plot) and bentgrass cultivars (subplot within overseeding date). Cultivar subplots were $0.75 \times 0.7 \mathrm{~m}$ with $0.075-\mathrm{m}$ untreated borders. Overseeding dates were 1 July, 18 Aug., and 18 Sept. 2000, and 27 June, 17 Aug., and 17 Sept. 2001. AB turf was mowed before overseeding to 3.2 $\mathrm{mm}$. A seedbed was prepared with a $15-\mathrm{mm}$ hollow-tine aerifier that cored to a depth of $38 \mathrm{~mm}$ in a $50 \times 64-\mathrm{mm}$ spacing. Cores were removed then a medium sized silica sand was topdressed to a 2.4-mm depth. Following topdressing, the turf was verticut to $10 \mathrm{~mm}$ depth with $3.2-\mathrm{mm}$ blades set $19 \mathrm{~mm}$ apart. Three creeping bentgrass cultivars ('Penncross', 'L-93', and 'Penn A-4'), one velvet bentgrass ('SR7200'), and a nonoverseeded check were evaluated. Seed mixed with a natural organic fertilizer $(5 \mathrm{~N}-2.2 \mathrm{P}-0 \mathrm{~K})$ was applied to each plot by hand with a shaker canister at a rate of $73 \mathrm{~kg} \cdot \mathrm{ha}^{-1}$ of seed and $\mathrm{N}$ at $37 \mathrm{~kg} \cdot \mathrm{ha}^{-1}$. Plots were then brushed by hand in two directions to incorporate the seed into coring holes and verticutting furrows, ensuring good seed to soil contact. Irrigation was applied by hand with a hose end spray nozzle at least twice a day for the first 3 weeks after overseeding to optimize bentgrass germination. Less frequent, heavier irrigation applications were applied as needed to avoid drought stress after emergence occurred. Fertilizer applications were made throughout the growing season from April to November at a rate of $\mathrm{N}$ at $24 \mathrm{~kg} \cdot \mathrm{ha}^{-1}$, for a total of $\mathrm{N}$ at $293 \mathrm{~kg} \cdot \mathrm{ha}^{-1}, \mathrm{P}$ at $32 \mathrm{~kg} \cdot \mathrm{ha}^{-1}$, and $\mathrm{K}$ at $122 \mathrm{~kg} \cdot \mathrm{ha}^{-1}$ over one growing season. After overseeding, the turf was mowed 5 times per week during the summer and three times per week during the spring and fall at a height of $3.2 \mathrm{~mm}$.

Bentgrass cover was visually estimated for each plot 1 month after overseeding (MAS) and 
Table 1. Percent bentgrass coverage as affected by overseeding (OS) and bentgrass cultivar in 2000 and 2001.

\begin{tabular}{|c|c|c|c|c|c|c|c|c|c|c|c|c|}
\hline \multirow[b]{4}{*}{ Cultivar-species } & \multicolumn{12}{|c|}{ Bentgrass coverage $(\%)$} \\
\hline & \multicolumn{3}{|c|}{$1 \mathrm{MAS}^{\mathrm{z}}$} & \multicolumn{3}{|c|}{$1 \mathrm{MAS}$} & \multicolumn{3}{|c|}{$1-4 \mathrm{MAS}^{\mathrm{y}}$} & \multicolumn{3}{|c|}{ 1-4 $\mathrm{MAS}^{\mathrm{w}}$} \\
\hline & \multicolumn{3}{|c|}{2000 OS date } & \multicolumn{3}{|c|}{2001 OS date } & \multicolumn{3}{|c|}{2000 OS date } & \multicolumn{3}{|c|}{2001 OS date } \\
\hline & 1 July & 18 Aug. & 18 Sept. & 27 June & 17 Aug. & 18 Sept. & 1 July & 18 Aug. & 18 Sept. & 27 June & 17 Aug. & 18 Sept. \\
\hline SR7200 velvet bentgrass & $13 \mathrm{aB}^{\mathrm{w}}$ & $10 \mathrm{aB}$ & $24 \mathrm{aA}$ & $8 \mathrm{aB}$ & $23 \mathrm{bA}$ & $27 \mathrm{aA}$ & $45 \mathrm{aA}$ & $37 \mathrm{aB}$ & $24 \mathrm{aC}$ & $25 \mathrm{aB}$ & $40 \mathrm{aA}$ & $27 \mathrm{abB}$ \\
\hline Penn A-4 creeping bentgrass & $12 \mathrm{aB}$ & $12 \mathrm{aB}$ & $23 \mathrm{aA}$ & $10 \mathrm{aC}$ & $28 \mathrm{aA}$ & $23 \mathrm{abB}$ & $40 \mathrm{aA}$ & $37 \mathrm{aA}$ & $23 \mathrm{aB}$ & $23 \mathrm{aB}$ & $40 \mathrm{aA}$ & $28 \mathrm{aB}$ \\
\hline L-93 creeping bentgrass & $12 \mathrm{aB}$ & $12 \mathrm{aB}$ & $23 \mathrm{aA}$ & $7 \mathrm{aB}$ & $20 \mathrm{bA}$ & $22 \mathrm{bA}$ & $42 \mathrm{aA}$ & $35 \mathrm{aB}$ & $23 \mathrm{aC}$ & $23 \mathrm{aB}$ & $37 \mathrm{aA}$ & $23 \mathrm{bB}$ \\
\hline Penncross creeping bentgrass & $11 \mathrm{aB}$ & $13 \mathrm{aB}$ & $24 \mathrm{aA}$ & $8 \mathrm{aC}$ & $27 \mathrm{aA}$ & $22 \mathrm{bB}$ & $39 \mathrm{aA}$ & $35 \mathrm{aA}$ & $24 \mathrm{aB}$ & $20 \mathrm{aB}$ & $38 \mathrm{aA}$ & $22 \mathrm{bB}$ \\
\hline
\end{tabular}

${ }^{\mathrm{z}} \mathrm{MAS}=$ month after overseeding.

'Evaluation taken on 18 Oct. 2001.

${ }^{x}$ Evaluation taken on 18 Oct. 2002.

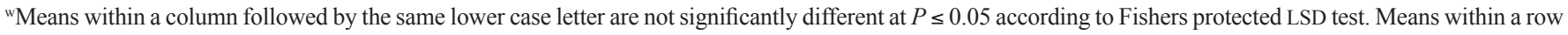
and a specific year of overseeding followed by the same uppercase case letter are not significantly different at $P \leq 0.05$ according to Fishers protected LSD test.

on 18 Oct. in the given year of overseeding $(1-4$ MAS) to evaluate initial establishment, and on 15 July 2001 and 2002 (12 and 24 MAS for the 2000 overseeding dates, and 12 MAS for the 2001 overseeding dates) to evaluate long term competitiveness. Bentgrass cover was also measured by line-intersect counts using a grid that contained 50 intersecting points. Both methods resulted in nearly identical values, thus only the visual estimates of bentgrass cover are presented. All data were subjected to an analysis of variance using PROC ANOVA and means were separated by the Fisher's Protected LSD test at the 0.05 probability level. Data were pooled across years to test for significant year interactions. The arcsine square root transformations of bentgrass cover data were also subject to ANOVA, but were not different from non-transformed data; therefore, the nontransformed data are presented.

\section{Results}

Analysis of variance revealed significant interactions for year by overseeding date for all data, and data are presented separately by year. There was a significant main plot effect of overseeding date $(P<0.001)$ in both years. Significant effects of cultivar $(P<0.001)$ and interactions between overseeding date and cultivar $(P<0.05)$ were observed for all data with the exception of the one MAS data after the 2000 overseeding dates.

$A B$ cover. $\mathrm{AB}$ maintained high levels of turfgrass cover ( $>95 \%$ in nonoverseeded plots) before the June-July overseeding in both years, and in the autumn and spring seasons throughout the course of the experiment. However, $\mathrm{AB}$ cover decreased to $90 \% \pm 4 \%, 88 \% \pm 5 \%$, and $91 \% \pm 3 \%$ in nonoverseeded plots (data not shown) throughout the summer seasons of 2000, 2001 and 2002, respectively.

Initial bentgrass establishment. Bentgrass establishment was evident at one MAS for all overseeding dates in 2000 and 2001 (Table 1). All bentgrass cultivars emerged uniformly within one week of planting with clearly distinguished rows corresponding with the verticut furrows. The 18 Sept. overseeding date had the highest initial bentgrass establishment in 2000 with bentgrass coverage ranging from $23 \%$ to $24 \%$ across all cultivars (Table 1 ). The 17 Aug. and 18 Sept. overseeding dates in 2001 had the highest initial bentgrass establishment with bentgrass coverage ranging from $20 \%$ to $28 \%$ across all cultivars.
Bentgrass coverage 1-4 MAS was greatest for the 1 July 2000 overseeding date ranging from $39 \%$ to $45 \%$ across all bentgrass cultivars (Table 1). Greater bentgrass coverage was observed for the 18 Aug. 2000 overseeding compared to the 18 Sept. 2000 overseeding date 1-4 MAS. Bentgrass coverage 1-4 MAS was greatest for the 17 Aug. 2001 overseeding date compared to the 27 June and 18 Sept. 2001 overseeding dates with coverage ranging from $37 \%$ to $40 \%$ across all cultivars (Table 1 ).

Firstyear conversion. Differences between overseeding dates in 2000 and 2001 and bentgrass cultivars became more apparent by July of the next growing season. Bentgrass conversion reached $68 \%$ for SR7200 in the 1 July 2000 overseeding date (Table 2). However, bentgrass coverage of 'Penncross' overseeded on 1 July 2000 declined substantially 12 MAS compared to observations taken 1-4 MAS, while bentgrass coverage for 'Penn A-4' and 'L-93' remained fairly constant at $45 \%$ and $48 \%$, respectively. Bentgrass coverage for 'PennA-4', 'L-93', and 'Penncross' overseeded

on 18 Aug. and 18 Sept. 2000 were $\leq 10 \% 12$ MAS, representing a substantial decline from 14 MAS. Percent cover of 'SR7200' overseeded on 18 Aug. and 18 Sept. 2000 also decreased, but maintained significantly higher bentgrass cover than other cultivars.

Bentgrass coverage increased for 'SR7200' overseeded on 27 June 2001 to $37 \%$, while coverage for 'Penn A-4' and 'L-93' remained fairly constant and 'Penncross' declined (Table 2). Bentgrass coverage for 'Penn A-4', 'L-93', and 'Penncross' overseeded on 17 Aug. and 18 Sept. 2001 decreased substantially, with coverage ranging from $7 \%$ to $15 \% 12 \mathrm{MAS}$, and were significantly lower than 'SR7200'.

Second year conversion. The 1 July 2000 overseeding had the greatest bentgrass conversion across all cultivars 24 MAS compared to the 17 Aug. and 18 Sept. 2000 overseeding dates (Table 3). Bentgrass conversion was greater for $17 \mathrm{Aug}$. 2000 overseeding than 18 Sept. 2000 overseeding for all cultivars except 'Penncross'. Populations of 'Penn A-4' and 'L-93' increased 24 MAS in the 1

Table 2. Percent bentgrass coverage as affected by overseeding (OS) date and bentgrass cultivar in 2001 and 2002 .

\begin{tabular}{|c|c|c|c|c|c|c|}
\hline \multirow[b]{4}{*}{ Cultivar-species } & \multicolumn{6}{|c|}{ Bentgrass coverage $(\%)$} \\
\hline & \multicolumn{3}{|c|}{$12 \mathrm{MAS}^{\mathrm{zy}}$} & \multicolumn{3}{|c|}{$12 \mathrm{MAS}^{\mathrm{x}}$} \\
\hline & \multicolumn{3}{|c|}{2000 OS date } & \multicolumn{3}{|c|}{2001 OS date } \\
\hline & 1 July & 18 Aug. & 18 Sept. & 27 June & 17 Aug. & 18 Sept. \\
\hline SR7200 velvet bentgrass & $68 \mathrm{aA}^{\mathrm{w}}$ & $23 \mathrm{aB}$ & $12 \mathrm{aC}$ & $37 \mathrm{aA}$ & $27 \mathrm{aB}$ & $22 \mathrm{aB}$ \\
\hline Penn A-4 creeping bentgrass & $45 \mathrm{bA}$ & $5 \mathrm{bB}$ & $5 \mathrm{bB}$ & $25 \mathrm{bA}$ & $13 \mathrm{bB}$ & $10 \mathrm{bB}$ \\
\hline L-93 creeping bentgrass & $48 \mathrm{bA}$ & $7 \mathrm{bB}$ & $5 \mathrm{bB}$ & $22 \mathrm{bA}$ & $15 \mathrm{bAB}$ & $12 \mathrm{bB}$ \\
\hline Penncross creeping bentgrass & $10 \mathrm{cA}$ & $5 \mathrm{bA}$ & $5 \mathrm{bA}$ & $8 \mathrm{cA}$ & $10 \mathrm{bA}$ & $7 \mathrm{bA}$ \\
\hline
\end{tabular}

${ }^{\mathrm{z}} \mathrm{MAS}=$ month after overseeding

yEvaluation taken on 15 July 2001.

${ }^{x}$ Evaluation taken on 15 July 2002.

wMeans within a column followed by the same lower case letter are not significantly different at $P \leq 0.05$ according to Fishers protected LSD test. Means within a row and a specific year of overseeding followed by the same uppercase case letter are not significantly different at $P \leq 0.05$ according to Fishers protected LSD test.

Table 3. Percent bentgrass coverage $24 \mathrm{MAS}^{z y}$ as affected by overseeding (OS) date in 2000 and bentgrass cultivar.

\begin{tabular}{lccr}
\hline & \multicolumn{3}{c}{ Bentgrass coverage (\%) } \\
\cline { 2 - 4 } Cultivar-species & \multicolumn{3}{c}{ OS date } \\
\cline { 2 - 4 } SR7200 velvet bentgrass & 1 July 2000 & 18 Aug. 2000 & 18 Sept. 2000 \\
Penn A-4 creeping bentgrass & $72 \mathrm{aA}$ & $30 \mathrm{aB}$ & $33 \mathrm{aB}$ \\
L-93 creeping bentgrass & $72 \mathrm{aA}$ & $15 \mathrm{bB}$ & $8 \mathrm{bB}$ \\
Penncross creeping bentgrass & $14 \mathrm{bA}$ & $17 \mathrm{bB}$ & $5 \mathrm{bC}$ \\
\hline
\end{tabular}

${ }^{\mathrm{z}} \mathrm{MAS}=$ month after overseeding.

yEvaluation taken on 15 July 2002.

${ }^{\mathrm{x}}$ Means within a column followed by the same lower case letter are not significantly different at $P \leq 0.05$ according to Fishers protected LSD test. Means within a row and a specific year of overseeding followed by the same uppercase case letter are not significantly different at $P \leq 0.05$ according to Fishers protected LSD test. 
July 2000 overseeding, eventually obtaining conversion similar to the amount achieved by 'SR7200' 12 MAS (Tables 2 and 3). 'SR7200', 'Penn A-4', and 'L-93' obtained 65\% coverage or more in the 1 July 2000 overseeding, in contrast to 'Penncross', which obtained only $16 \%$ coverage. 'SR 7200 ' had the greatest bentgrass coverage in the 17 Aug. and 18 Sept. 2000 overseeding dates, with $30 \%$ and $33 \%$, respectively.

\section{Discussion}

September overseeding had the greatest initial establishment (at 1 month) of bentgrass in both years, but an early summer overseeding in late June or early July was better for longterm bentgrass conversion. Traditionally, late summer has been the preferred time to seed cool-season turfgrasses, because soil temperatures are conducive to seed germination and summer annual weed pressure is less (Beard, 1973; Toole and Kock, 1977). Since AB is a winter annual, it exhibits high germination potential in late summer and early fall and low germination potential from late spring to early summer (Beard et al., 1978; Kaminski and Dernoeden, 2002). Recent studies showed that late summer and fall seeding dates were at greatest risk of $\mathrm{AB}$ invasion, while a June seeding date produced the greatest establishment of bentgrass (Murphy et al., 1999).

Results from this study indicate that 'SR7200' velvet bentgrass and 'Penn A-4' and 'L-93' creeping bentgrass cultivars have a greater potential for conversion of $\mathrm{AB}$ to bentgrass than Penncross when overseeded in early summer. Researchers have suggested that the higher shoot densities of the newer creeping bentgrass cultivars provide increased competition with AB (Beard et al., 2001). These researchers observed shoot densities that ranged from 2000 to 2700 shoots $/ \mathrm{dm}^{2}$ with newer bentgrass cultivars 'Penn G-2', 'Penn A-1', and 'Seaside II' when maintained at a cutting height of $3.2 \mathrm{~mm}$, while older creeping bentgrass cultivars 'Penncross', 'Penneagle', and 'Providence' had shoot densities that ranged from 1300 to 1800 shoots $\mathrm{dm}^{-2}$. Thus, creeping bentgrass cultivars that maintained shoot densities above 2000 shoots $/ \mathrm{dm}^{2}$ exhibited the most competitiveness against $\mathrm{AB}$ encroachment. Velvet bentgrasses have also been identified as stoloniferous grasses that have fine leaf texture and very high shoot density (DeFrance et al., 1952; Sprague and Evaul, 1930).

Few studies have been conducted to evalu- ate the potential of gradual conversion through the overseeding of bentgrass into AB. To date, research conducted on gradual conversion has had only limited success. Gaussoin et al. (1989) obtained no more than $8 \%$ bentgrass conversion of a mixed $\mathrm{AB}$-creeping bentgrass stand after 3 years of overseeding with 'Penncross' in Michigan. Our data and that of Beard et al. (2001) indicates that limited conversion may have been due to the use of 'Penncross' creeping bentgrass. Moreover, the $\mathrm{AB}$-creeping bentgrass stand was not aerified nor topdressed before overseeding, which might have reduced seed to soil contact, limiting initial establishment. Lastly, overseeding in Michigan was conducted in August, so environmental conditions during initial establishment may have been more equivalent to conditions that are found during September in New Jersey. Reicher et al. (2002) observed no more than $3 \%$ bentgrass conversion of a mature $A B$ fairway after 3 years of overseeding 'Penneagle' creeping bentgrass. 'Penneagle' also exhibits poor competition with AB (Beard et al., 2001). Minimal conversion in this study may also be attributed to the use of spring and fall overseeding dates when $\mathrm{AB}$ is most competitive with creeping bentgrass. Minimal conversion in both studies (Gaussoin et al. 1989, Reicher et al. 2002) may also be attributed to the indigenous and more mature $\mathrm{AB}$ stand, which was likely more competitive with creeping bentgrass, than the newly seeded AB stand used in our study.

Although we had success in converting AB to bentgrass with early summer overseeding dates and use of newer cultivars we must consider that the likelihood of success may be lower on a predominantly indigenous $\mathrm{AB}$ golf course putting green that is well established. Although the AB turf cover was high, the quality was unacceptable in the summer months, particularly for a putting green surface. The AB exhibited summer decline as evidenced by the reductions in turf cover during the summer months and is the likely reason for the high degree of success in the June-July overseeding dates. Other factors such as intensive foot traffic and ball marking that tend to promote $\mathrm{AB}$ infestation were not present in this study.

Results from this study suggest that successful conversion of $\mathrm{AB}$ to predominantly bentgrass may be more probable using early summer overseeding dates and improved bentgrass cultivars. Additional research needs to be conducted to determine if these practices could be used to successfully convert an indigenous, well established $\mathrm{AB}$ putting green to bentgrass.

\section{Literature Cited}

Beard, J.B. 1970. An ecological study of annual bluegrass. USGA Green Sect. Rec. 8(2):13-18.

Beard, J.B. 1973. Turfgrass: Science and culture. Prentice-Hall, Englewood Cliffs, N.J.

Beard, J.B., P.E. Rieke, A.J. Turgeon, and J.M. Vargas. 1978. Annual bluegrass (Poa annиa L.) description, adaptation, culture and control. Mich. State Univ. Agr. Expt.Sta. Res. Rpt. 352.

Beard, J.B., P. Croce, M. Mocioni, A. De Luca, and M. Volterrani. 2001. The comparative competitive ability of thirteen Agrostis stolonifera cultivars to annual bluegrass. Intl. Turfgrass Soc. Res. J. 9:828-831.

Bonos, S.A., K.A.Plumley, W.A. Meyer, J.A. Murphy, B.B. Clarke, W.K. Dickson, J.B. Clark, and D.A. Smith. 2001. Performance of bentgrass cultivars and selections in New Jersey turf trials, p. 1-21. In: A.B. Gould (ed.). Rutgers turfgrass proceedings. vol. 33. Rutgers Ctr. Turfgrass Sci, New Brunswick, N.J.

Carroll, J.C. 1943. Effects of drought, temperature and nitrogen on turfgrasses. Plant Physiol. 18:19-36.

Christians, N. 1998. Fundamentals of turfgrass management. Ann Arbor Press, Chelsea, Mich.

Croce, P., M. Mocioni, and J.B. Beard. 1998. Agrostis cultivar characterizations for closely mowed putting greens in a Mediterranean climate, $\mathrm{p}$. 668-678. In: M.R.Farrally and A.J. Cochran (eds.). Science and golf III. Proc. 3rd World Sci. Congr. Golf, St. Andrews, U.K.

DeFrance, J.A., T.E. Odland, and R.S. Bell. 1952. Improvement of velvet bentgrass by selection. Agron. J. 44:376-378.

Gaussoin, R.E. and B.E. Branham. 1989. Influence of cultural factors on species dominance in a mixed stand of annual bluegrass/creeping bentgrass. Crop Sci. 29:480-484.

Kaminski, J.A. and P.H. Dernoeden. 2002. Seasonal germination of annual bluegrass in Maryland. Agron. Abst. 123-013 (CD Rom).

Lush, W.M. 1989. Adaptation and differentiation of golf course populations of annual bluegrass. Weed Sci. 37:54-59.

Murphy, J.A., J.A. Honig, and T.J. Lawson. 1999. Seeding date and bentgrass cultivar effects on annual bluegrass invasion. Agron. Abst. 91:140.

Reicher, Z.J. and G.A. Hardebeck. 2002. Overseeding strategies for converting golf course fairways to creeping bentgrass. HortScience 37(3):508-510.

Sprague, H.B. and E.E. Evaul. 1930. Experiments with turfgasses in New Jersey, p. 1-55. N.J. Agr. Expt. Sta. Bul. 497.

Sprague, H.B. and G.W. Burton. 1937. Annual bluegrass (Роа аппиа $\mathrm{L}$.), and its requirements for growth, p. 1-24. N.J. Agr. Expt. Sta. Bul. 630.

Sweeney, P. and K. Danneberger. 1997. Annual bluegrass segregation on greens and fairways. Golf Course Mgt. 65(4):49-52.

Toole, V.K. andE.J.Kock. 1977. Light and temperature control of dormancy and germination in bentgrass seeds. Crop Sci. 17:806-811.

Turgeon, A.J. 1996. Turfgrass management. PrenticeHall, Upper Saddle River, N.J.

Wehner, D.J. and T.L. Watschke. 1981. Heat tolerance of kentuckybluegrasses, perennial ryegrasses, and annual bluegrass. Agron. J. 73:79-84. 